\title{
Corporate Governance Determinants for The Mitigation of The Likelihood of Financial Distress
}

\author{
Hafiz Mahmud Ahmad ${ }^{1}$, Desi Adhariani ${ }^{1 *}$ \\ ${ }^{1}$ Department of Accounting, Faculty of Economics and Business, Universitas Indonesia \\ Email: desi.adhariani@ui.ac.id
}

\begin{abstract}
This study aims to examine the effect of corporate governance factors on the likelihood of a company being exposed to financial distress. The factors investigated are the nature of ownership (family or institutional), the proportion of independent directors, and the sizes of the audit committee, board of directors, and board of commissioners. The period studied is 2011 - 2015 using samples of non-financial companies in Indonesia with a total of 190 observations. Data collection is conducted through paired matching, specifically by matching financial report data from 95 observations indicated to experience financial distress with 95 "healthier" observations from the same industry sector, same period, and similar asset size. Binary Logistic Regression is used in this study. The results show that family ownership, the size of the board of directors, the size of the board of commissioners, and the size of the audit committee have significant roles in preventing companies from experiencing financial distress, while institutional ownership and the proportion of independent directors are found to have no effect. Although not all hypotheses are supported in this research, the findings assert the important role played by corporate governance in mitigating the likelihood of financial distress.
\end{abstract}

Type of paper: Empirical

Keywords: financial distress, corporate governance, ownership, audit committee, board of directors, board of commissioners

\section{Introduction}

The economic and financial crisis in Indonesia and other Asian countries in the 1990s highlighted the important consequences of the financial problems of stakeholders, such as creditors, investors, employees, regulators, and the public in general. The crisis occurred partly due to many companies' inability to anticipate financial distress, thus leading to their insolvency. Financial distress itself is a condition in which the company is unable to maintain its going concern, which brings about consequences in the form of bankruptcy, delisting, or organizational restructuring (Muller et al., 2009). 
Analysis of the causes of financial distress and the development of better and more stable predictive models of financial distress are not new. In fact, since the 1960s there have been many models for predicting financial distress and bankruptcy developed by Beaver (1966, 1968), Altman $(1968,1982)$ or Ohlson (1980) among others.

The literature on financial distress mentioned two important issues as potential causes, namely: a. the inability of credit institutions and financial creditors to anticipate and prevent situations of financial distress; and $b$. ignorance about the importance of the effectiveness of corporate governance mechanisms in this context (Husson-Traore, 2009). The examples for this are the cases of the Lehman Brothers bankruptcy in 2008 and Enron in 2001; and the cases of PT Kimia Farma in 2001 and Lippo bank in 2003 in Indonesia.

In Indonesia, the implementation of corporate governance has recently gained critical attention from the top management in various companies and regulatory bodies such as the Central Bank (Bank Indonesia) and the Financial Services Authority (Otoritas Jasa Keuangan). Analysis of the relationship between the characteristics of corporate governance in Indonesia and financial distress has been discussed in previous research, such as the one conducted by Wardhani (2006), which shows that the greater the size of board of commissioners, the lower the likelihood of companies being exposed to financial distress, while ownership by financial institutions and managers did not produce significant results.

This study aims to examine, using the latest data, the association between corporate governance mechanisms and the possibility of financial distress in listed companies in Indonesia. This study uses an estimate of financial distress from Manzaneque et. al. (2016), in which a company is classified as experiencing financial distress if these conditions are met: Revenue before interest, taxes, depreciation and amortization (EBITDA) was lower than the financial expenses for two consecutive years. This proxy is used as an indication of a company's financial distress based on the fact that, if the company becomes more dependent on bank loans and its revenues tend to decrease for two consecutive periods, then the company is indicated to be financially troubled and the going concern in the future is questionable. Data used by Manzaneque et. al. (2016) was a sample of non-financial companies in the period 2008 to 2012. This study uses data of non-financial companies listed on the Indonesia Stock Exchange from 2011 to 2015, which should reflect a more recent condition.

\section{Literature Review}

\subsection{Agency Theory}

To overcome agency problems in a company, corporate governance is deemed to play a significant role in reducing agency conflicts between the management and the owner, and between majority and minority shareholders. One mechanism for this is manifested through the role of audit committee to ensure that the shareholders' interests are properly protected.

The other mechanism is through family ownership, which can reduce the conflicts of agency between shareholders and creditors when there is an alignment effect by reducing the potential of earnings management. For institutional ownership, Moh'd et. al. (1998) explains that stock distribution to outsiders can reduce agency costs. This is because ownership is a 
source of power that can be used to support or challenge the existing management, thus the concentration or even distribution of power is a relevant issue within the company.

Corporate governance is underpinned by the agency theory, where it is stated that agency issues will arise if the management of a company is separate from its ownership. Boards of commissioners and directors have an important role in an enterprise given the authority to manage the company and make decisions on behalf of the owner. The authority in the hands of managers enables them to act contrary to the company's objectives due to a conflict of interest (Riyanto, 2003).

\subsection{Good Corporate Governance}

Corporate governance is a set of relationships between corporate management, boards, shareholders, and other stakeholders. Corporate governance also provides the structure through which the goals of a company are set, and how performance monitoring is determined. Good Corporate Governance should provide the right incentives for the management to achieve the company's objectives and shareholders' interests by facilitating effective oversight, thereby encouraging companies to use their resources more efficiently (The Organization for Economic Cooperation and Development Principles of Corporate Governance, 2004).

\subsection{Development of Hypotheses}

\subsubsection{Effect of Family Ownership on Corporate Financial Distress}

Family ownership in a company plays a role in reducing agency conflicts within the company due to a reduction in conflict between the principal and the agent. This improves the company's performance and can keep the company away from financial problems (Arifin, 2003). This explains why family firms can reduce conflicts that could adversely affect company performance.

In addition, according to Maury (2005), family control can help improve the performance of the company due to its impact on profitability; he also indicated that family ownership can help reduce agency issues between the owner and the manager of a company. In accord with Arifin (2003) and Maury (2005), Chu (2009) in his research also found that family ownership had a positive relationship with the performance of a company, and a positive relationship between family ownership and firm performance would be strengthened when there are family members in the management of a company.

Based on the explanation above, the first hypothesis is formulated as follows:

$\mathrm{H}$ : $\quad$ Family ownership has a negative effect on the likelihood of corporate financial distress.

\subsubsection{Effect of Institutional Ownership on Corporate Financial Distress}

Some studies have analyzed the influence of institutional investors (such as investment firms, insurance companies, pension funds, and mutual funds) upon the survival of companies. They demonstrated their effectiveness as a corporate governance mechanism in monitoring the management (Blair, 1995; Daily, 1995) and in their focus on long-term performance rather than short-term or annual management (Donker et al, 2009). Thus, it is expected that in the context 
of concentrated ownership, where other corporate governance mechanisms may be ineffective, institutional investors may take an active role in controlling the management. In contrast, other authors demonstrate a lack of expertise among institutional investors in providing advice to the management (Gillan and Starks, 2000) and their incentive to behave passively against management when they have a business relationship (Donker et al, 2009. Daily and Dalton (1994), Firth, Chung, and Kim (2005) and Mangena and Chamisa (2008) found a negative association between institutional investors and the company's likelihood of financial distress. Campbell et. al. (2008) found that the risk of financial distress was negatively associated with institutional ownership. Based on these previous studies, the second hypothesis is formulated as follows:

$\mathrm{H} 2$ : Institutional ownership has a negative effect on the likelihood of corporate financial distress.

\subsubsection{Effect of Audit Committee Size on Corporate Financial Distress}

For a company to get better management and control it is recommended to have an audit committee to improve supervision over management and operational activities. Usually, the effectiveness of an audit committee would increase when the number of the committee members is increased. The findings from McMullen and Raghunandan (1996) provide evidence that a competent and high-quality audit committee can reduce the likelihood of companies experiencing financial problems, and that the presence of accounting experts is positively associated with fewer misstated financial statements. Besides the positive association with size, the effectiveness of an audit committee can also increase with more working experience in other companies. The hypothesis can be developed as follows.

H3: The size of the audit committee has a negative effect on the likelihood of corporate financial distress.

\subsubsection{Effect of the Proportion of Independent Directors on Corporate Financial Distress}

Gueyie and Elloumi (2001) and Wang and Deng (2006) concluded that companies with a higher proportion of independent directors are likely to experience financial distress due to the fact that they are more efficient in imposing actions needed to help resolve possible failure situations (Fich and Slezak, 2008). Chang (2009) also pointed out that the presence of independent directors, in the long run, resulted in the development of efficient activities that will detect and monitor the possible emergence of opportunistic behavior by the management in order to avoid business failures. Meanwhile, Chaganti et al. (1985), Simpson and Gleason (1999) and Lajili and Zéghal (2010) found no such relationship. According to the agency theory, it can be hypothesized that the proportion of independent directors is negatively related to financial difficulties. Based on these arguments, the hypothesis is as follows:

H4: The proportion of Independent Directors has a negative effect on the likelihood of corporate financial distress.

\subsubsection{Effect of the Size of the Board of Directors on Corporate Financial Distress}

Chaganti et. al. (1985) revealed several problems related to larger size for the board of directors. In this case, larger boards may present problems with balance since the decisions approved by the majority may be to the detriment of the public interest, or they may lack effectiveness when a volatile economic environment requires changes in strategic direction. However, according to Emrinaldi (2007), the larger the size of the board of directors in a company, the less likely 
the company is to experience financial distress due to diversity of background that may lead to better decisions and policies. Based on these arguments, the hypothesis is as follows:

H5: The size of the board of directors has a negative effect on the likelihood of corporate financial distress.

\subsubsection{Effect of the Size of the Board of Commissioners on Corporate Financial Distress}

Previous studies (Chaganti et al., 1985; Fich and Slezak, 2008) have discussed the effect of the board of commissioners on companies' financial distress. However, we must note that the research was conducted in countries that use the one-tier board system except for the work undertaken by Santen and Soppe (2009), which was conducted in the Netherlands when the country was still using the $\neg$ two-tier system (before the switch to one-tier boards in 2013). Previous research has found that a larger size for the board of commissioners in a company would tend to increase the likelihood of financial distress due to inefficient communication and coordination. Based on these arguments, the hypothesis is formulated as follows:

H6: The size of the board of commissioners has a positive effect on the likelihood of corporate financial distress.

\section{Research Methods}

The model used in this study was adapted from Manzaneque et al. (2016) as follows:

$$
\begin{aligned}
\mathrm{FD}= & \beta_{0}+\beta_{1} \mathrm{FF}_{\mathrm{it}}+\beta_{2} \text { OWNERSIG }_{\mathrm{it}}+\beta_{3} \mathrm{PID}_{\mathrm{it}}+\beta_{4} \mathrm{SIZEAC}_{\mathrm{it}}+\beta_{5} \text { SIZEDIR }_{\mathrm{it}}+ \\
& \beta_{6} \mathrm{SIZEKOM}_{\mathrm{it}}+\beta_{7} \mathrm{PROF}_{\mathrm{it}}+\beta_{8} \mathrm{FE}_{\mathrm{it}}+\beta_{9} \mathrm{RE}_{\mathrm{it}}+\mathrm{B}_{10} \mathrm{SIZE}_{\mathrm{it}}
\end{aligned}
$$

Information:

FD

: Dummy variable that has a value of 1 when the company suffers financial distress and 0 otherwise. A company is considered to experience financial distress when the following conditions are met: Earnings before interest, taxes, depreciation, and amortization (EBITDA) are lower than the financial expenses of a company for up to two years in a row.

FF : Family Ownership is a dummy variable specified with a value of 1 , and 0 otherwise

OWNERSIG : The percentage of institutional ownership

SIZEAC : The number of members of the Audit Committee within the company

PID : : The proportion of independent directors in the board of Directors

SIZEDIR : The number of members of the Board of Directors

SIZEKOM : The number of members of the Board of Commissioners

PROF : profit before interest and taxes to total assets at the beginning of the period $\left(\mathrm{EBIT}_{\mathrm{t}} / \mathrm{RTA}_{\mathrm{t}-1}\right)$

FE : The financial expenses, which is the ratio of interest, income taxes, and other costs associated with ownership or rent of an asset or property, to total assets at the beginning of the period $\left(\mathrm{FE}_{\mathrm{t}} / \mathrm{RTA}_{\mathrm{t}-1}\right)$

RE : Reinvested earnings or losses of a company during the life of the company compared to total assets at the beginning of the period $\left(\mathrm{RE}_{\mathrm{t}-1} / \mathrm{RTA}_{\mathrm{t}-1}\right)$

SIZE : Company size, measured by natural logarithm of total assets 
Table 1. Sample Selection

\begin{tabular}{lr}
\hline \multicolumn{1}{c}{ Criteria } & Number of companies \\
\hline Companies listed in the Stock Exchange 2011-2015 & 2470 \\
\hline 2011-2015 financial sector companies & $(411)$ \\
\hline $\begin{array}{l}\text { Companies that are not exposed to financial distress 2011-2015 } \\
\text { based on criteria used in this study }\end{array}$ & 95 \\
\hline $\begin{array}{l}\text { Companies indicated to experience financial distress 2011-2015 } \\
\text { based on criteria used in this study with complete data }\end{array}$ & 95 \\
\hline Non-financial distressed companies 2011-2015 for matched pairing & $\mathbf{1 9 0}$ \\
\hline Total observations & \\
\hline
\end{tabular}

Table 2. Descriptive statistics

\begin{tabular}{lccrrrrrr}
\hline \multirow{2}{*}{ Variable } & \multicolumn{4}{c}{ Number of Observations: 95 (Distress) } & \multicolumn{2}{c}{ Number of Observations: 95 (Non-Distress) } \\
\cline { 2 - 11 } & Mean & Std. Dev & Min & Max & Mean & Std. Dev & \multicolumn{1}{l}{ Min } & Max \\
\hline FF & 0.419 & 0.319 & 0 & 0.984 & 0.615 & 0.259 & 0 & 0.989 \\
\hline OWNERSIG & 0.276 & 0.278 & 0 & 0.875 & 0.233 & 0.286 & 0 & 0.873 \\
\hline SIZEAC & 2.4 & 1.307 & 0 & 4 & 2.621 & 1.102 & 0 & 5 \\
\hline PID & 0.128 & 0.161 & 0 & 0.5 & 0.136 & 0.163 & 2 & 0.5 \\
\hline SIZEDIR & 3.631 & 1.360 & 2 & 9 & 4.231 & 1.801 & 2 & 13 \\
\hline SIZECOM & 3.694 & 1.523 & 2 & 9 & 3.4 & 1.241 & 2 & 7 \\
\hline PROF & -0.050 & 0.105 & -0.693 & 0.341 & 0.184 & 0.606 & -0.228 & 4.208 \\
\hline FE & 0.030 & 0.043 & $3.47 \mathrm{E}-06$ & 0.255 & 0.030 & 0.026 & 0.000 & 0.142 \\
\hline RE & -0.765 & 1.407 & -9.068 & 0.727 & -0.222 & 1.506 & -9.068 & 4.504 \\
\hline SIZE (Ln) & 27398 & 1.440 & 22657 & 30647 & 27506 & 1.324 & 24008 & 30898 \\
\hline
\end{tabular}

PID $=$ The proportion of independent directors; OWNERSIG $=$ Institutional Ownership; SIZEAC $=$ Number of Members in the Audit Committee; SIZEDIR = Number of Members in the Board of Directors; SIZECOM = Number of Members in the Board of Commissioners; PROF $=$ EBIT divided by total assets of the previous period; $\mathbf{F E}=$ Financial Expenses divided by total assets of the previous period; $\mathbf{R E}=$ Retained earnings divided by total assets before; SIZE $(\mathbf{L n})=$ Firm Size (in logarithm); FF $=$ percentage of family ownership

\subsection{Data collection technique}

In this study, 95 companies are categorized as companies experiencing financial problems in the period 2011 to 2015 with complete data on corporate governance and finance. The selection procedure of companies not experiencing financial distress for the match-pair design is based on the following criteria:

- Non-financial companies listed in the Indonesia Stock Exchange

- The partner company must come from the same industry sector and sub-sector; for example, if the distressed company is a transport company, it must be paired with a non - distressed company in the transport sub-sector as well.

- The paired companies must be in the same financial period and have similar asset sizes. Measurement of the difference between the company's assets is conducted using sample paired t-test.

\section{Results and Analysis}

\subsection{Descriptive statistics}

The descriptive statistics after a winsorizing procedure are presented in Table 2. 
Table 3. Results of Logistic Regression

\begin{tabular}{|c|c|c|c|c|c|c|}
\hline Distress & $\begin{array}{l}\text { Expected } \\
\text { Sign }\end{array}$ & Coef. & Odds Ratio & $\mathbf{z}$ & $\mathbf{P}>|\mathbf{z}|$ & Sig \\
\hline $\mathrm{FF}$ & $(-)$ & -2.6483 & 0.0707 & -3.44 & 0.000 & $* * *$ \\
\hline OWNERSIG & $(-)$ & 0.0165 & 1.0166 & 0.02 & 0.496 & \\
\hline SIZEAC & $(-)$ & -0.2652 & 0.7669 & -1.39 & 0.083 & $*$ \\
\hline PID & $(-)$ & -1.6904 & 0.1844 & -1.28 & 0.100 & $*$ \\
\hline SIZEDIR & $(-)$ & -0.4239 & 0.6544 & -2.47 & 0.006 & $* * *$ \\
\hline SIZECOM & $(+)$ & 0.3786 & 1.4603 & 1.97 & 0.025 & $* *$ \\
\hline PROF & $(-)$ & -17.9309 & $1.63 \mathrm{E}-08$ & -5.77 & 0.000 & $* * *$ \\
\hline $\mathrm{FE}$ & $(+)$ & 5.0563 & 157.0197 & 0.72 & 0.236 & \\
\hline $\mathrm{RE}$ & $(-)$ & 0.1744 & 1.1905 & 0.99 & 0.185 & \\
\hline SIZE & $(-)$ & -0.0280 & 0.9723 & -0.17 & 0.434 & \\
\hline LR chi2(10) & 112.65 & & & & & \\
\hline Prob $>$ chi2 & 0.0000 & & & & & \\
\hline Pseudo R2 & 0.4277 & & & & & \\
\hline
\end{tabular}

*** significant at $\alpha 1 \%$;* significant at $\alpha 5 \%$; * significant at $\alpha 10 \%$;

PID $=$ The proportion of independent directors; OWNERSIG $=$ Institutional Ownership; SIZEAC $=$ Number of Members in the Audit Committee; SIZEDIR $=$ Number of Members in the Board of Directors; SIZECOM $=$ Number of Members in the Board of Commissioners; PROF $=$ EBIT divided by total assets of the previous period; $\mathbf{F E}=$ Financial Expenses divided by total assets of the previous period; RE = Retained earnings divided by total assets before; SIZE (Ln) =Firm Size (in logarithm); FF = percentage of family ownership

Some important points from Table 2: it can be seen that the percentage of family ownership in companies with financial problems has an average of 0.4198 , while in companies that do not have financial problems the average is 0.6151 . Based on these comparisons, it can be said that the overall percentage of family ownership in non-distressed companies is much higher than that in distressed companies, despite having the same maximum percentage value.

The average number of members in audit committees is 2.4 in distressed firms and 2.62 in nondistressed firms, indicating that the size of audit committees in non-distressed firms tends to be higher when compared to distressed firms. The minimum value is 0 because there are many companies that still don't have an internal audit committee, although the number of companies with internal audit committees increased over time in the period 2014-2015. The maximum value is 4 for distressed companies, namely PT Pelat Timah Nusantara Tbk and PT Asia Pacific Investama Tbk, and 5 for a non-distressed company, PT Malindo Feedmill Tbk.

\subsection{Hypothesis Testing}

The results of hypothesis testing are presented in Table 3.

The results of the logistic regression shows that family ownership in a company has a possible negative influence upon the possibility of financial distress with an effect size of only 0.07 , so it can be concluded that the first hypothesis is accepted. This finding is in line with Arifin's (2003) statement that-family owned companies listed on the Indonesia Stock Exchange are less likely to have agency conflicts between principals and agents. This improves the companies' performance and helps them avoid financial problems. The findings are also in line with Maury's (2005) conclusion that family controls can improve the company's performance, affecting company profits and suppressing conflicts between owners and managers. 
Institutional ownership is found to have no effect upon the possibility of companies experiencing financial distress, which confirms Edelen (2001) and Fich and Slezak (2008) that institutional owners do not have sufficient institutional strength or more incentives to make the company perform better. The number of members in audit committees has a negative influence on financial distress, which is in line with Collier (1993) who found that the existence of audit committees can assist the board of directors in fulfilling statutory and mandatory responsibilities, namely maintaining the quality of financial statements and maintaining the quality of internal control systems in a company. The proportion of independent directors shows a negative influence, which is consistent with Gueyie and Elloumi (2001)'s and Wang and Deng (2006)'s findings that the higher proportion of independent directors in a company makes them more efficient in terms of overcoming possible failure situations.

The number of members in a company's board of directors has a negative influence by only 0.6 to the possibility of financial distress in the company, which is consistent with Pearce and Zahra (1992) and Pfeffer (1972) in that a larger board of directors offer more advantages to the company's ability to access more diverse resources and information needed to achieve the company's objectives. The number of members in boards of commissioners is found to have a positive influence on financial distress, which is in line with Daily and Dalton (1994) and Jensen (1993).

\subsection{Sensitivity Test}

Two sensitivity tests were conducted to check the robustness of the findings. Firstly, the measurement of family ownership was changed from a percentage to a dummy variable like in Pindado et. al. (2008): 1 if the family ownership is above $10 \%$ and 0 otherwise. The results only show a change in the variable of the proportion of independent directors, which becomes insignificant. Secondly, the sensitivity test is only conducted on manufacturing companies and the results show that family ownership and the size of audit committees have no effect, while institutional ownership is found to have significant association with the likelihood of financial distress. This means that the corporate governance regimes applied in a specific industry might have different effects compared to other industries in terms of their effects upon the likelihood of financial distress. Regardless, it can be said that the results of the sensitivity analysis are consistent with the main test.

\section{Conclusion}

This study aims to examine the effects of corporate governance, relating the influence of the variables of family ownership, institutional ownership, proportion of independent directors, size of the audit committee, size of the board of directors, and size of the board of commissioners upon the likelihood of a company experiencing financial distress, using a sample of nonfinancial companies listed on the Indonesia Stock Exchange (BEI) in the period 2011 to 2015. The results show that family ownership, the size of audit committees, the proportion of independent directors, the size of boards of directors, and the size of boards of commissioners had a significant role in mitigating the probability of financial distress in a company.

Although not all hypothesis are supported in this study, the major results confirm the important role played by corporate governance mechanisms in mitigating the likelihood of financial distress. The straightforward implication is that companies should maintain good corporate 
governance in order to achieve better performance and avoid the possibility of financial distress. For future studies, we suggest that the mechanisms be studied in detail by applying other research methods, such as a case study in companies indicated to experience financial distress based on certain criteria.

\section{References}

Altman, E. (1968). Financial ratios, discriminant analysis and the prediction of corporate bankruptcy. Journal of Finance, 23, 589-609.

Arifin, Z. (2003). Masalah Agensi dan Mekanisme Kontrol pada Perusahaan dengan Struktur Kepemilikan Terkonsentrasi yang Dikontrol Keluarga: Bukti dari Perusahaan Publik di Indonesia. Disertasi, Universitas Indonesia.

Beaver, W. (1966). Financial ratios as predictors of failure. Journal of Accounting Research, 4, 71-111.

Blair, M. (1995). Ownership and control: Rethinking corporate governance for the twenty-first century. Washington DC: The Brookings Institution.

Campbell, J.Y., Hilscher, J., Szilagyi, J.A.N., (2008). In Search of Distress Risk. Journal of Finance 63, 2899-2939.

Chaganti, R., Mahajan, V., \& Sharma, S. (1985). Corporate board size, composition, and corporate failures in retailing industry. Journal of Managment Studies, 22, 400-417.

Chang, C. (2009). The corporate governance characteristics of financially distressed firms: Evidence from Taiwan. Journal of American Academy of Business, 15, 125-132.

Chu, W. (2009). The influence of family ownership on SME performance: evidence from public firms in Taiwan. Small Business Economic, 33, 353-373.

Collier, P., \& Gregory, A. (1996). Audit committee effectiveness and the audit fee. European Accounting Review, 5(2), 177-198.

Daily, C., \& Dalton, D. (1994). Bankruptcy end corporate governance: The impact of board composition and structure. Academy of Mangement Journal, 37, 1603-1617.

Daily, C. (1995). An empirical examination of the relationship between CEOs and directors. Journal of Business Strategies, 12, 50-68.

Donker, H., Santen, B., \& Zahir, S. (2009). Ownership structure and the likelihood of financial distress in the Netherlands. Applied Financial Economics, 19, 1687-1696.

Emrinaldi. (2007). Analisis Pengaruh Praktek Tata Kelola Perusahaan (Corporate Governance) Terhadap Kesulitan Keuangan Perusahaan (Financial Distress) : Suatu Kajian Empiris. Jurnal Bisnis dan Akuntansi, Vol. 9, No. 1. 
Fich, E., \& Slezak, S. (2008). Can corporate governance save distressed firms from bankruptcy? An empirical analysis. Review of Quantitative Finance and Accounting, 30, 225-251.

Firth, M., Chung, R., \& Kim, J. (2005). Earnings management, surplus free cash flow, and external monitoring. Journal of Business Research, 58, 766-776.

Gillan, S. L., \& Starks, L. T. (2000). Corporate governance proposals and shareholders activism: The role of institutional investors. Journal of Financial Economics, 57, 275-305.

Gueyie, F., \& Elloumi, J. (2001). Financial distress and corporate governance: An empirical analysis. Corporate Governance, 1, 15-23.

Husson-Traore, A. C. (2009). More effective corporate governance. Organization for economic cooperation and development. The OECD Observer. ProQuest Central., p. 50.

Jensen, M. (1993). The modern industry revolution, exit, and the failure of internal control systems. Journal of Finance, 48, 831-880.

KNKG (2006). "Pedoman Umum Good Corporate Governance Indonesia"

Manzaneque, M. (2016). Caracterización y Predicción de los Desenlaces del Fracaso Empresarial (Doctoral thesis). Spain: Facultad de Ciencias Sociales, Universidad de Castilla-La Mancha.

Maury, B. ( 2005). Family ownership and firm performance: Evidence from Western European Corporations. Journal of Corporate Finance, 12, 321-341.

McMullen, D.A., \& Raghunandan, K. (1996). Enhancing audit committee effectiveness. Journal of Accountancy, 182, 79-81

Moh'd, et al. (1998). The Impact of Ownership Structure on Corporate Debt Policy: a TimeSeries Cross Sectional Analysis. Financial Review 33. Page 85-98.

Muller, G., Steyn-Bruwer, B., \& Hamman, W.(2009). Predicting financial distress of companies listed on the JSE - a comparison of techniques. South African Journal of Business Management, 40(1), 21 - 32.

Ohlson, J. A. (1980). Financial ratios and the probabilistic prediction of bankruptcy. Journal of Accounting Research, 18, 109-131.

Organization for Economic Co-operation Development. (2004). OECD Principles of Corporate Governance, OECD Publication Service.

Pearce, J., \& Zahra, S. (1992). Board compensation from a strategic contingency perspective. Journal of Mangement Studies, 29, 411-438.

Pindado, J., Rodrigues, L., \& De la Torre, C. (2008). Estimating financial distress likelihood. Journal of Business Research, 61, 995-1003. 
Santen, B., Soppe, A., (2009). NED characteristics, board structure and management turnover in the Netherlands in times of financial distress: a theoretical and empirical survey. Corporate Ownership and Control 7, 17,

Simpson, W., \& Gleason, A. (1999). Board structure, ownership, and financial distress in banking firms. International Review of Economics and Finance, 8, 281-292.

Wang, Z., \& Deng, X. (2006). Corporate governance and financial distress. The Chinese Economy, 39, 5-27.

Wardhani, Ratna. (2006). Mekanisme Corporate Governance dalam Perusahaan yang Mengalami Permasalahan Keuangan. SNA IX Padang. 